\title{
Does the Historical Literature on Encephalitis Lethargica Support a Simple (Direct) Relationship with Postencephalitic Parkinsonism?
}

\author{
Joel A. Vilensky, $\mathrm{PhD},{ }^{1 *}$ Sid Gilman, $\mathrm{MD},{ }^{2}$ and Sherman $\mathrm{McC}$ all, $\mathrm{MD}^{3}$ \\ ${ }^{I}$ Department of Anatomy and Cell Biology, Indiana University School of Medicine, Fort Wayne, Indiana, USA \\ ${ }^{2}$ Department of Neurology, University of Michigan School of Medicine, Ann Arbor, Michigan, USA \\ ${ }^{3}$ Department of Clinical Pathology, US Army Medical Research Institute of Infectious Diseases (USAMRIID), \\ Fort Detrick, Maryland, USA
}

\begin{abstract}
This article and the subsequent one suggest that the currently accepted view of a simplistic (direct) relationship between encephalitis lethargica (EL) and postencephalitic Parkinsonism (PEP) is based on a incomplete evaluation of the epidemic period literature. In this article we provide a detailed analysis of the literature from the period that demonstrates that Parkinsonism was not initially part of acute EL symptomatology, that PEP was not typically the prevailing type of chronic EL and that oculogyric crises were never part
\end{abstract}

of acute EL symptomatology and not initially associated with PEP. The second paper uses these finding, and also examines the clinical justifications for concluding that all patients with PEP had prior acute episodes of EL, to reevaluate the presumed direct etiologic relationship between EL and PEP. (C) 2010 Movement Disorder Society

Key words: epidemic encephalitis; von Economo's disease; encephalitic Parkinsonism; oculogyric crises
Postencephalitic Parkinsonism (PEP) is currently perceived as having a very close etiologic relationship with encephalitis lethargica (von Economo's disease; EL), with PEP developing either immediately after the acute phase of EL or at some time (weeks to many years) later. This relationship between EL and PEP was based on the observation that EL patients could have a form of EL, the amyostatic-akinetic form, in which they showed many parkinsonian features, and on the perception that some EL patients seemed to pass seamlessly from the acute phase of EL to PEP. ${ }^{1}$ This

*Correspondence to: Dr. Joel A. Vilensky, Indiana University School of Medicine, 2101 E. Coliseum Blvd., Fort Wayne, IN 46805 E-mail: vilensk@ipfw.edu

Potential conflict of interest: Nothing to report.

Received 23 April 2009; Revised 17 July 2009; Accepted 11 December 2009

Published online 14 May 2010 in Wiley InterScience (www. interscience.wiley.com). DOI: 10.1002/mds.22991 observation and perception led to the modern view that PEP is the predominant (and perhaps) only permanent sequel to EL.

In this article, we trace historically the development of PEP, the amyostatic-akinetic form of EL, and oculogyric crises (OCs; which are intimately associated with PEP; cf. below) to better understand the perceived relationship among them. The purpose of this analysis is to demonstrate that some of the currently accepted aspects of EL and PEP do not accurately reflect the epidemic period literature. Furthermore, the data detailed here provide critical support for the second article of this pair, which argues that the relationship between EL and PEP is more complex than currently believed, i.e., that the virus that presumably caused EL alone may not be the cause of PEP.

The selection of references that form the bases of these article was unbiased in that we searched our collection of EL literature (over 2500 publications) for 


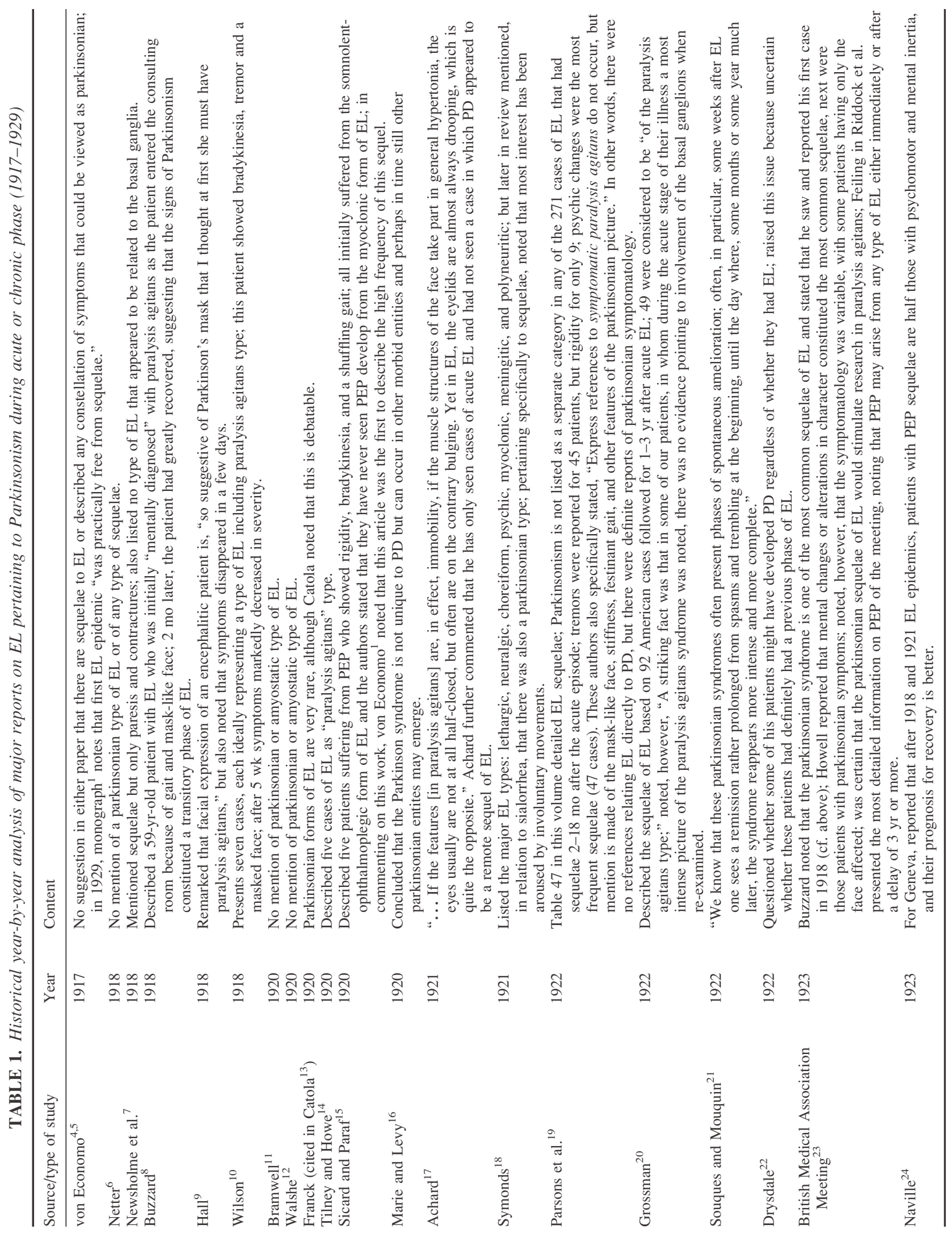




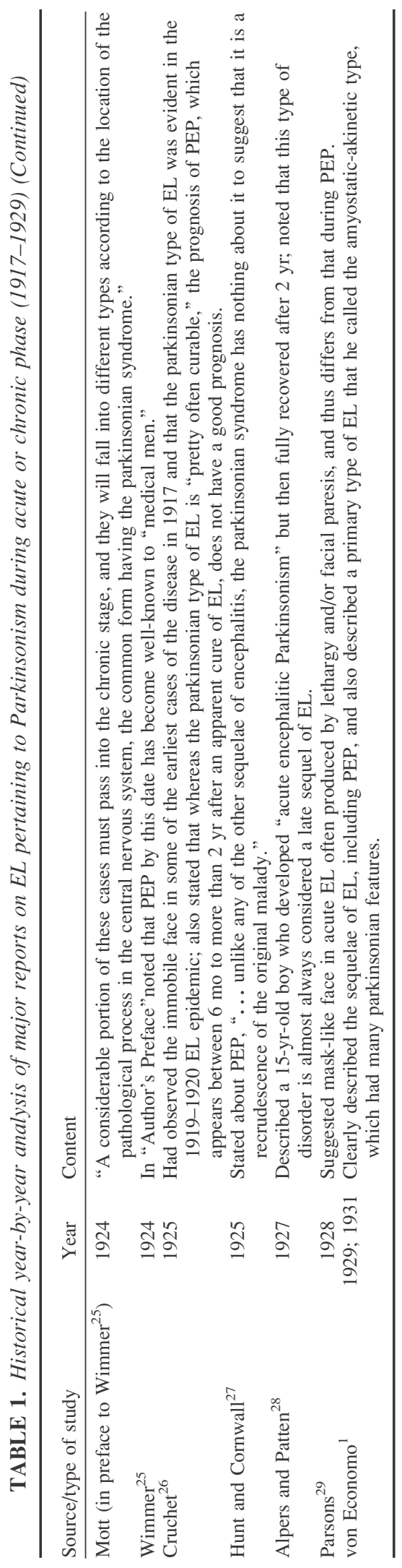

relevant articles from the epidemic period (1917-1929) and later that presented some information/view on the amyostatic type of EL, EL sequelae, OCs and/or PEP. We emphasize here that our review includes articles published in the three major languages of the time, English, French, and German. Furthermore, to facilitate readability, we have placed much of the supporting literature in tabular form; thus, the reader is free to consult the tables for these data but the article is fully comprehensible without reference to the tables. Finally, in the tables, where we include quotes from non-English articles, we only include the English translation (to conserve space).

\section{HISTORICAL REVIEW OF EL REPORTS PERTAINING TO PARKINSONISM}

In two 1980s article on EL/PEP, parkinsonian signs were considered to be important for diagnosing EL.,3 However, parkinsonian signs were not part of von Economo's original description of the acute disease ${ }^{4}$ and some authors initially considered them to be transitory (Table 1).

Similarly, parkinsonian signs were not considered part of the chronic syndrome until about 3 years after von Economo's 1917 initial description and not firmly associated with chronic EL until about by 1924 (see Wimmer in Table 1). And, during this period there were consistent questions as to the relationship between PEP and idiopathic Parkinsonism (PD), with some clinicians of the time (especially the French clinicians) insisting that PEP and PD were identical (including etiology). ${ }^{17,30,31}$

Additionally, the amyostatic-akinetic form of EL was not a consistent form of EL. Von Economo ${ }^{1}$ stated that the amyostatic form of EL was particularly prevalent in some EL epidemics, such as that in London in 1918, and Hamburg in 1919. And, Cruchet ${ }^{26}$ indicated that the greatest number of patients with this type of EL was observed between November 1919 and April 1920. We also note in Table 1 a comment by Franck that the parkinsonian form of EL may have been rare, but Franck was not a well-known EL authority.

Lastly, virtually all recent reviews of EL only mention the three types of EL highlighted by von Economo (somnolent-opthalmoplegic, hyperkinetic, and amyostatic-akinetic). ${ }^{32-34}$ However, there were actually many more types categorized; we listed 28 types in a previous publication ${ }^{35}$ including some that would seem very unrelated to Parkinsonism (e.g., cerebellar, hemiplegic, spinal, polyneuritic, autonomic, tabetic, myelitic, thalamic, and juvenile pseudo-psychopathia). It is 
TABLE 2. Number of cases of PEP and other sequelae of EL

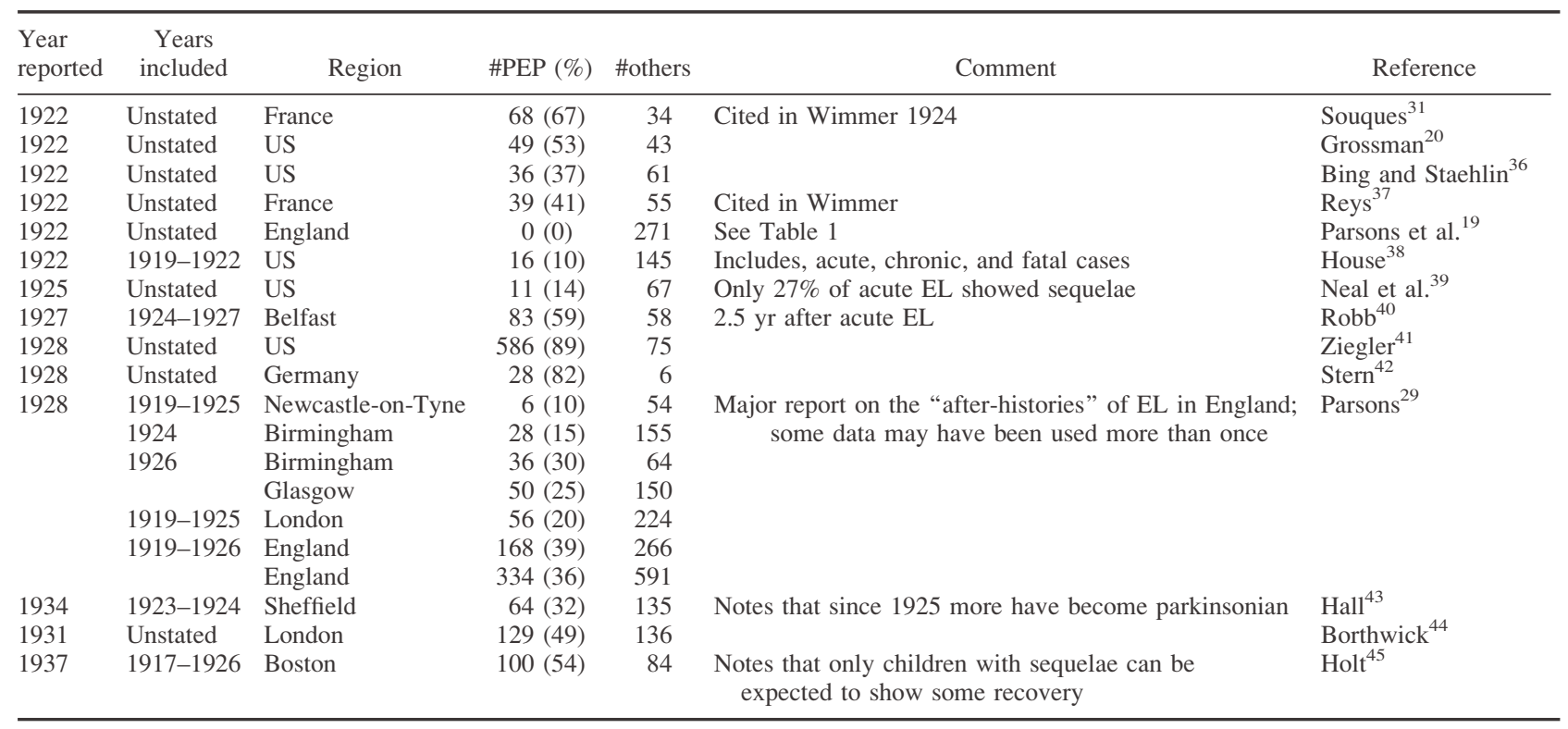

unclear how often any of these "types" including the amyostatic-akinetic type led to PEP or even if all of these types represented the same condition.

The importance of these data (Table 1) is to demonstrate that EL was not initially associated with Parkinsonism and, even later, some doubted this relationship or believed PEP and PD to be the same. Why this is so is not entirely clear but it suggests that there were some fundamental changes in the syndrome over time and thus the relationship between EL and PEP may not be as direct or consistent as it is currently perceived to be.

\section{PEP VERSUS OTHER FORMS OF CHRONIC EL}

Table 2 presents all the available actual numerical data for the number of PEP cases versus other forms of chronic EL that were reported from 1922-1937. The reported percentage of EL patients who immediately or eventually developed PEP symptomatology is very variable, ranging from no cases to the vast majority. Certainly, this variability related to definitional aspects of PEP as well as to the timeframe used to record the patient's history. On the basis of the data in Table 2, it is difficult to accept the premise that the vast majority of EL cases eventually developed PEP as advocated by Duvoisin and Yahr in $1965^{46}$ or the statement by Dourmashkin in $1997^{47}$ that, "the outstanding motor manifestation [of the chronic form] was the parkinsonian syndrome, present in almost every case." Rather, nonPEP sequelae (especially psychiatric) were common during the epidemic period and will likely still be prevalent should EL recur. The lack of attention to these non-PEP sequelae ${ }^{47}$ have undoubtedly skewed the perception toward accepting a direct relationship between EL and PEP.

\section{OCULOGYRIC CRISES}

OCs are now considered almost a pathognomonic sign of $\mathrm{PEP}^{48}$ and it is doubtful that they were described prior to the EL epidemic period (but see Jeliffe in Table 3). Nevertheless, this sign was not clearly identified until 1921 (4 years after EL was defined), and even then only putatively (Table 3). Thus, OCs were not part of the constellation of signs that were associated with the earliest descriptions of PEP and certainly were not considered part of acute EL symptomatology (von Economo never listed them as being associated with acute EL). Accordingly, considering OCs to be a sign consistent with a diagnosis of acute EL is incorrect (see Refs. ${ }^{2}$ and ${ }^{3}$ ), although most modern putative cases of EL consider them inherent to the disease (e.g., Refs. ${ }^{65}$ and ${ }^{66}$ ). That OCs are not part of acute EL symptomatology but are considered part of PEP symptomatology ${ }^{48}$ raises some questions as to the continuity between the two conditions. Furthermore, that OCs were not initially recognized in PEP also raises questions about whether there were some changes in EL and/or PEP during the epidemic period, suggesting perhaps that these were not unitary syndromes. Accordingly, Wilson in the EL chapter in 
TABLE 3. Historical year-by-year account of oculogyric crises

\begin{tabular}{|c|c|c|}
\hline Source & Year & Comment \\
\hline Oeckinghaus ${ }^{49}$ & 1921 & $\begin{array}{l}\text { Reported that in October 1920, after sleeping for } 8 \text { wk uninterrupted because of EL, a } \\
\text { farmer's } 15 \text {-yr-old daughter complained of her eyes rolling up. }\end{array}$ \\
\hline $\operatorname{Lemos}^{50}$ & 1924 & First description of OCs in France. \\
\hline Fischer, ${ }^{51}$ Meyer, ${ }^{52}$ and Ewald ${ }^{53}$ & 1924 & $\begin{array}{l}\text { First description of OCs in Germany; Fischer noted that he could find no prior references } \\
\text { to this type of ocular movement. }\end{array}$ \\
\hline Geimanowitsch et al. ${ }^{54}$ & 1924 & First description of OCs in Russia. \\
\hline Hohman $^{55}$ & 1925 & $\begin{array}{l}\text { Presented the first description of OCs in the US (four cases) and noted that he could find } \\
\text { no prior references to this type of ocular movement; considered OCs to be a late onset } \\
\text { sign of PEP, although they occurred as soon as } 1 \mathrm{yr} \text { after the onset of parkinsonian } \\
\text { signs in one case. }\end{array}$ \\
\hline Barkas $^{56}$ & 1926 & $\begin{array}{l}\text { Earliest British accounts of OCs; almost all cases were associated with chronic EL, almost } \\
\text { always of the parkinsonian type. }\end{array}$ \\
\hline Wimmer $^{57}$ & 1926 & Indicated that OCs occur 4-7 yr after the development of chronic EL. \\
\hline McCowan and Cook ${ }^{58}$ & 1928 & $\begin{array}{l}\text { Reported that the earliest occurrence of OCs was } 6 \text { mo after EL onset, but they } \\
\text { consistently appeared at least } 1 \text { mo after the onset of parkinsonian signs; also noted that } \\
\text { the incidence of OCs was increasing; reported an incidence of } 17 \% \text { among } 136 \\
\text { institutionalized encephalitics and saw their first OCs in 1923; stated that there was no } \\
\text { relationship to any specific epidemic; their patients developed their initial EL episodes } \\
\text { from } 1919 \text { until } 1925 \text {. }\end{array}$ \\
\hline Collier $^{59}$ & 1928 & OCs virtually exclusively in the "parkinsonian syndrome of lethargic encephalitis." \\
\hline Bramwell $^{60}$ & 1928 & $\begin{array}{l}\text { Stated that there was no mention of OCs in the literature before } 1923 \text { and noted that, in } 11 \\
\text { cases, they were consistently associated with manifestations of Parkinsonism; described } \\
\text { the sign as pathognomonic (our italics) and was sometimes of diagnostic importance } \\
\text { because the accompanying Parkinsonism signs were too slight to be recognizable. }\end{array}$ \\
\hline Critchley $^{61}$ & 1928 & $\begin{array}{l}\text { Commented on the rarity of OCs, which occurred in only } 5.6 \% \text { of his } 72 \text { cases; noted that } \\
\text { they are only found as part of the parkinsonian syndrome and that they may be } \\
\text { becoming more frequent; observed that during a crisis the patient does not lose } \\
\text { consciousness, but may have hallucinations. }\end{array}$ \\
\hline Taylor and McDonald ${ }^{62}$ & 1928 & OCs only occur in PEP. \\
\hline Bennett and Patton ${ }^{63}$ & 1930 & $\begin{array}{l}\text { Reported that OCs, although a postencephalitic residual, may occur without any other } \\
\text { parkinsonian sign, and presented one case as an example. }\end{array}$ \\
\hline Jelliffe ${ }^{64}$ & 1932 & $\begin{array}{l}\text { Postulated that OCs had been observed before the epidemic of EL, were not solely present } \\
\text { in EL/PEP patients, were not an isolated phenomenon, and were typically associated } \\
\text { with some affective disturbances; hence, viewed them as secondary (functional) } \\
\text { phenomena associated with psychiatric processes; also noted that OCs tended to occur } \\
\text { late in the disease process, not during acute EL but during the chronic phase; although } \\
\text { he maintained that OCs had occurred earlier than the } 1920 \text { s, the descriptions he } \\
\text { presented from earlier times are not convincingly representative of OCs. }\end{array}$ \\
\hline
\end{tabular}

his 1940 book, Neurology, ${ }^{67}$ stated that, “... there is reason to believe the 'encephalitis' [EL] is not identical at all times and locations, and it may cover states of dissimilar etiology."

\section{CONCLUSIONS}

As might be expected, the relationship among EL, PEP, PD, and OCs during the 1920s was clearly "muddled," not only by diagnostic problems, but presumably also by language, communication issues (some associated with World War I) and the presumed delay in onset of PEP. PEP was not considered a sequel of EL by all epidemic period clinicians, and some considered it virtually the same as PD. These factors plus the lack of any clear diagnostic criteria for EL led us to question the assertion that EL led directly to PEP. In the next article we follow-up on this one, using the presented data and information on the post hoc rediagnosis of EL after the development of PEP, to suggest that the relationship between EL and PEP is not as direct as currently perceived and that PEP, similar to other parkinsonian disorders, had multifactorial causation.

Acknowledgments: Support for this research was provided by the Sophie Cameron Trust (www.thesophiecamerontrust.org.uk). Ms. Hope Owens and Dr. Roger Duvoisin provided the French translations, and Dr. Paul Foley and Mr. Kris Kallmeyer provided the German translations. Mr. Richard Steele provided constructive criticism on prior versions of this manuscript and reviewers provided very detailed and helpful criticisms of earlier versions of this manuscript.

Financial Disclosures: Nothing to report.

Author roles: All three authors contributed to all aspects of conceiving, writing and revising this manuscript.

\section{REFERENCES}

1. von Economo C. Die Encephalitis lethargica, ihre Nachkrankheiten und ihre Behardlung. Berlin: Urban and Schwarzenberg; 
1929.251p (published in English in 1931: translated by Newman KO. London: Oxford University Press; 200 p).

2. Howard RS, Lees AJ. Encephalitis lethargica: a report of four recent cases. Brain 1987;110:19-33.

3. Rail D, Scholtz C, Swash M. Post-encephalitic parkinsonism: current experience. J Neurol Neurosurg Psychiatry 1981;44: 670-676.

4. von Economo C. Encephalitis lethargica. Wien Klin Wochenschr 1917;30:581-585.

5. von Economo C. Neue beiträge zur encephalitis lethargica. Neurol Centralblatt 1917:5;866-878.

6. Netter A. Encephalite lethargique epidemique. Bull Acad Natl Med 1918;1xxix:337-347.

7. Newsholme A, James SP, MacNalty AS, et al. Report of an enquiry into an obscure disease, encephalitis lethargica. Reports to the local government board on public health and medical subjects (new series 121). London: Printed under the authority of His Majesty's Stationery Office by Jas Truscott and Son; 1918. $74 \mathrm{p}$.

8. Buzzard EF. Acute epidemic encephalitis (letter). Lancet 1918; 1:715.

9. Hall AJ. Epidemic encephalitis. Br Med J 1918;2:461-463.

10. Wilson SAK. Epidemic encephalitis. Lancet 1918;2:7-12,91.

11. Bramwell E. Encephalitis lethargica. Lancet 1920;1:1152-1158.

12. Walshe FMR. On the symptom-complexes of lethargic encephalitis with special reference to involuntary muscular contractions. Brain 1920;xliii:197-219.

13. Catola G. A propos de l'evolution et du pronostic du parkinsonisme postencephalitique. Rev Neurol 1921;28:694-715.

14. Tilney F, Howe HT. Epidemic encephalitis (encephalitis lethargica). New York: Paul B. Hoeber; 1920. 252 p.

15. Sicard JA, Paraf J. Parkinsonnisme et Parkison, reliquats d'Encephalite epidemique. Rev Neurol 1920;xxvii:465-470.

16. Marie P, Lévy G. Le syndrome parkinsonien dans l'encéphalite léthargique. Bull Acad Natl Med 1920;83:539-545.

17. Achard le P. L'encephalite lethargique. Paris: Librairie J.B. Bailliere Et Fils; 1921. 325 p.

18. Symonds CP. Critical review: encephalitis lethargica. Q J Med 1921;14:283-308.

19. Parsons AC, MacNalty AS, Perdrau JR. Public health and medical subjects report on encephalitis lethargica: being an account of further enquiries into the epidemiology and clinical features of the disease; including an analysis of over 1,250 reports of cases notified in England and Wales during 1919 and 1920, together with a comprehensive bibliography of a subject. Reports on Public Health and Medical Subjects, No. 11. London: His Majesty's Stationery Office; $1922.74 \mathrm{p}$.

20. Grossman M. Sequels of acute epidemic encephalitis. JAMA 1922;78:959-962.

21. Souques A, Mouquin M. Inefficacite du traitement des syndromes Parksinsoniens postenecephalitiques par les injections intraveineuses de liquide caphalo-rachidein du malade. Rev Neurol 1922;29:1356-1359.

22. Drysdale HH. Parkinson's disease as sequelae to lethargic encephalitis. Ohio State Med J 1922;xviii:842-849.

23. Buzzard EF. Discussion on the sequelae of lethargic encephalitis. Br Med J 1923;2:1085-1090.

24. Naville F. Sequelae of epidemic encephalitis. Rev Med Suisse Romande 1923:43:1-27.

25. Wimmer A. Chronic epidemic encephalitis. London: William Heinemann; 1924.335p; Mott cited in Preface.

26. Cruchet $\mathrm{R}$. The relation of paralysis agitans to the parkinsonian syndrome of epidemic encephalitis. Lancet 1925;2:263-268.

27. Hunt EL, Cornwall LH. The postencephalitic Parkinson syndrome. JAMA 1925;84:29-32.

28. Alpers BJ, Patten CA. Acute encephalitic parkinsonism. JAMA 1927;88:1387-1389.

29. Parsons AC. Report of an inquiry into the after-histories of persons attacked by encephalitis lethargica. Reports on public health and medical subjects, No. 49. London: His Majesty's Stationery Office; 1928. $179 \mathrm{p}$.

30. Goodhart SP, Cottrell SS. Residua and sequelae of epidemic encephalitis. JAMA 1925;84:32-36; Petren cited in Discussion.

31. Souques MA. Rapport sur les syndromes Parkinsoniens. Rev Neurol 1922;37:534-573.

32. Blunt SB, Lane RJM, Turjanski N, Perkin GD. Clinical features and management of two cases of encephalitis lethargica. Mov Disord 1997;12:354-359.

33. Dickman MS. von Economo encephalitis. Arch Neurol 2001; 58:1696-1598.

34. Reid AH, McCall S, Henry JM, Taubenberger JK. Experimenting on the past: the enigma of von Economo's encephalitis lethargica. J Neuropathol Exp Neurol 2001;60:663-670.

35. Vilensky JA, Gilman S. Encephalitis lethargica: could this disease be recognised if the epidemic recurred? Pract Neurol 2006; 6:360-367.

36. Bing R, Staehelin R. Epidemic encephalitis. JAMA 1922;78: 1008 .

37. Reys L. L'encephalite epidemique. Clin Ophthamol 1923;27: $438-451$.

38. House WB. Epidemic encephalitis. J Am Inst Homeopath 1929;5: 139-149.

39. Neal JB, Jackson HW, Appelbaum E. A study of four hundred and fifty cases of epidemic encephalitis. Am J Med Sci 1925; 170:708-722.

40. Robb AG. Epidemic encephalitis: the proportion of permanent recoveries. BMJ 1927;1:615-616.

41. Ziegler LH. Follow-up studies on persons who have had epidemic encephalitis. JAMA 1928;91:138-141.

42. Stern F. Die epidemische encephalitis. Berlin: Springer; 1928. $541 \mathrm{p}$.

43. Hall AJ. Prognosis and treatment of chronic epidemic encephalitis. Practitioner 1934;133:26-36.

44. Borthwick GA. The sequelae of epidemic encephalitis. Clin J 1928;60:510-514, 521-524.

45. Holt WL. Epidemic encephalitis: a follow-up study of two hundred and sixty-six cases. Arch Neurol Psychiatry 1937;38:11351144.

46. Duvoisin RC, Yahr MD. Encephalitis and parkinsonism. Arch Neurol 1965;12:227-239.

47. Dourmashkin RR. What caused the 1918-30 epidemic of encephalitis lethargica? J R Soc Med 1997;90:515-520.

48. Litvan I, Jankovic J, Goetz CG, et al. Accuracy of the clinical diagnosis of postencephalitic parkinsonism: a clinicopathologic study. Eur J Neurol 1998;5:451-457.

49. Oeckinghaus E. Encephalitis epidemica and Wilsonsches Krankheitsbild. Dtsche Z Nervenheilkd 1921;72:294-309.

50. Lemos M. Claudication intermittente, crampe des ecrivains, deviation conjubuee de la tete et des yeus, spasme des muscles masticateurs glosso-palato-larynges et des membres superieurs, apparus au cours du syndrome parkinsonien encephalite prolongeelocalisation striee probable. Rev Neurol 1924;2:425-449.

51. Fischer B. Uber vestibulare Beeinflussung der Augenmuskelstarre bei der Encephalitis epidemica. Dtsche Z Nervenheilkd 1924;81: 164-169.

52. Meyer A. Beitrage zur Encephalitis epidemica. Arch Psychiatr Nervenkr 1924;70:466-528.

53. Ewald G. Schauanfälle als postenzephalitische Störung (Zugleich ein Beitrag zur Frage psychischer Störungen bei postenzephalitischen Zuständen). Monatsschr Psychiatr Neurol 1924;57: 222-253.

54. Geimanowitsch A, Beilien B, Leschschenko G. Augenmuskelsymptome bie epidemischer Encephalitis. Z Gesamte Neurol Psychiatr 1924;38:146.

55. Hohman LB. The histo-pathology of post-encephalitic Parkinson's syndrome. Bull Johns Hopkins Hosp 1925;36:403-410.

56. Barkas M. Tonic spasms of the eyes in conjugate deviation. Lancet $1926 ; 2: 330$. 
57. Wimmer A. Tonic eye fits ("oculogyric crises") in chronic epidemic encephalitis. Acta Psychiatr Neurol 1926;1:173-187.

58. McCowan PK, Cook LC. Oculogyric crises in chronic epidemic encephalitis. Brain 1928;51:285-309.

59. Collier J. The ocular complications of encephalitis lethargica. Proc R Soc Med 1928;21(Part 2):985-996.

60. Bramwell E. The upward movements of the eyes. Brain 1928;1:1-17.

61. Critchley AM. Ocular manifestations following encephalitis lethargica. Bristol Med Chir J 1928;45:113-124.

62. Taylor EW, McDonald CA. Forced conjugate upward movement of the eyes following epidemic encephalitis. Arch Neurol Psychiatry $1928 ; 19: 95-103$.
63. Bennett AE, Patton JM. Oculogyric crises in postencephalitic states. Arch Ophthalmol 1930;4:361-367.

64. Jelliffe SE. Psychopathology of forced movements and the oculogyric crises of lethargic encephalitis. New York: Nervous and Mental Disease Publishing Co.; 1932. 219 p.

65. Dale RC, Church AJ, Surtees RAH, et al. Encephalitis lethargica syndrome: 20 new cases and evidence of basal ganglia autoimmunity. Brain 2004;127:21-33.

66. Lopez-Alberola R, Georgiou M, Sfakianakis GN, Singer C, Papapetropoulos S. Contemporary encephalitis lethargica: phenotype, laboratory findings and treatment outcomes. J Neurol 2009;256:396-404.

67. Wilson SAK. Neurology. Baltimore, MD: The Williams and Wilkins Company; 1940. 805 p. 